\title{
Analisis Sentimen Netizen Twitter terhadap Pemberitaan PPN Sembako dan Jasa Pendidikan dengan Pendekatan Social Network Analysis dan Naive Bayes Classifier
}

\author{
Joko Ade Nursiyono ${ }^{(1)}$, Chusnul Chotimah ${ }^{(2)}$ \\ Badan Pusat Statistik Provinsi Jawa Timur \\ Jl. Raya Kendangsari Industri No 43-44 Telp. (031) 8439343 Surabaya 60292 \\ e-mail: joko.ade@bps.go.id dan chus_chot@bps.go.id
}

\begin{abstract}
ABSTRAK
Pandemi covid-19 yang terjadi memberikan dampak di berbagai bidang kehidupan. Salah satu dampaknya penerimaan negara semakin tertekan hebat. Padahal di sisi lain negara dalam proses pemulihan ekonomi nasional (PEN) yang membutuhkan dana sangat besar. Sehingga pemerintah ingin menggenjot pendapatan negara dari pajak pertambahan nilai (PPN). Jika pemungutan PPN dapat dilakukan dengan seoptimal mungkin, maka akan meningkatkan penerimaan negara. Rencana tersebut mengakibatkan maraknya pemberitaan mengenai pengenaan PPN sembako dan jasa pendidikan di Indonesia. Pemberitaan tersebut secara otomatis memicu opini di masyarakat. Salah satu cara untuk melihat opini masyarakat adalah melalui media sosial Twitter. Penelitian ini bertujuan untuk mengkaji network dan sentimen netizen Twitter tentang PPN Sembako dan jasa pendidikan menggunakan metode betweenness centrality dan Naive Bayes Classifier. Social Network Analisis (SNA) menghasilkan 5 klaster dengan record ke-90 merupakan bottleneck node, yaitu aktor utama penyebaran informasi antar klaster. Model Naive Bayes Classifier memberikan hasil Accuracy Classified sebesar 74.865 persen, sementara persentase Incorrectly Classified Instance sebesar 25.135 persen. Hasil klasifikasi berdasarkan emosi terbentuk 5 ekspresi fear, sadness, surprise, joy, dan anger dengan emosi kata terbanyak adalah emosi anger (amarah), artinya mayoritas respon masyarakat terhadap kebijakan pengenaan PPN sembako dan jasa pendidikan diidentifikasikan oleh $R$ Studio sebagai wujud keamarahan.
\end{abstract}

Kata kunci : PPN, Sembako, Sentimen, Emosi Kata, Social Network Analisis, Naive Bayes Classifier.

\begin{abstract}
The COVID-19 pandemic has had an impact on many areas of life. One of the effects of state revenues is getting severely depressed. Whereas on the other hand, the country is in the process of national economic recovery $(P E N)$ which requires very large funds. So the government wants to boost state revenue from valueadded tax (VAT). If VAT collection can be carried out optimally, it will increase state revenue. The plan resulted in widespread news regarding the imposition of VAT on necessities and education services in Indonesia. The news automatically triggers public opinion. One way to see public opinion is through social media Twitter. This study aims to examine more deeply the network and sentiments of Twitter netizens about VAT for necessities and education services using betweenness centrality and Naive Bayes Classifier methods. The results of Social Network Analysis (SNA) resulted in 5 clusters with the 90th record being a bottleneck node, which is the main actor in disseminating information between clusters. The Naive Bayes Classifier model gives for Accuracy Classified it is 74,865 percent, while the percentage for Incorrectly Classified Instance is 25,135 percent. The results of the classification based on emotions formed 5 expressions of fear, sadness, surprise, joy, and anger and the emotion with the most words was anger, meaning that the majority of public responses to the policy of imposing VAT on necessities and education services were identified by $R$ Studio as an anger emotion.
\end{abstract}

Keywords : VAT, Basic Food, Sentiment, Word Emotion, Social Network Analysis, Naive Bayes Classifier.

\section{PENDAHULUAN}

Pandemi covid-19 yang terjadi memberikan dampak di berbagai bidang kehidupan. Menurut Neilmardin (2021), salah satu dampaknya membuat penerimaan kas negara semakin tertekan hebat. Padahal di sisi lain negara dalam proses pemulihan ekonomi nasional (PEN) yang membutuhkan dana sangat besar. Sehingga pemerintah ingin menggenjot pendapatan negara dari pajak pertambahan nilai (PPN). Tarif PPN Indonesia yang dipatok sebesar 10 persen terlalu rendah jika dibandingkan negara lain di dunia yang menerapkan

Joko Ade Nursiyono ${ }^{1}$, Chusnul Chotimah ${ }^{2} /$

J Statistika Vol. 14 No. 1, (2021) 
Pajak Pertambahan Nilai atau Value Added Tax (VAT) dan Goods and Services Tax (GST). Struktur penerimaan negara dari PPN selama ini memiliki kontribusi sebesar 42 persen terhadap penerimaan negara. Jika pemungutan PPN dapat dilakukan dengan seoptimal mungkin, maka akan meningkatkan penerimaan negara sebagai bekal berbagai program pembangunan. Rencana tersebut mengakibatkan maraknya pemberitaan mengenai pengenaan PPN sembako dan jasa pendidikan di Indonesia. Pemberitaan tersebut secara otomatis memicu opini di masyarakat.

Opini yang terbentuk tentu menimbulkan sentimen sekaligus pro dan kontra di media sosial. Tingkat dan kecepatan penyebaran informasi ditentukan oleh seberapa besar pengaruh sebuah akun seseorang dalam jejaring media sosial, terutama Twitter. Melalui pendekatan Social Network Analysis (SNA), penelitian ini bertujuan untuk menentukan aktor utama sekaligus pengaruhnya dalam model penyebaran informasi (Setatama, Mahdi, S. dan Tricahyono, Dodie, 2017) atau opini antar klaster. Selain itu, untuk mengetahui sentimen yang terbentuk dari wacana pengenaan PPN sembako maupun jasa pendidikan, penilitian ini menggunakan pengklasifikasian emosi kata model Naive Bayes Classifier. Menurut Nurzahputra, Aldi dan Muslim, Much A.(2016), dalam text mining, pendekatan Naive Bayes Classifier bisa digunakan untuk mengklasifikasikan opini ke dalam opini positif dan negatif.

\section{METODE PENELITIAN}

\section{Set Data}

Set data yang digunakan dalam penelitian ini bersumber dari Twitter yang diperoleh dengan teknik Crawling menggunakan $R$ Studio versi 4.0.3. Dari sebanyak 5.000 target records yang akan digunakan sebagai sampel, didapatkan sebanyak 4.090 records yang terdiri atas 90 variabel. Adapun periode records yang tercatat sebagai sampel penelitian ini mulai 10 Juni 2021 - 21 Juni 2021. Setelah itu dilakukan pembersihan data teks (text cleaning) dengan tahapan seperti pada gambar 1 .

\section{Import data}

Import data dilakukan dengan menggunakan library readxl kemudian menyeleksi kalimat tweet pada data untuk kemudian dijadikan sebagai data corpus melalui library corpus.

\section{Text Cleaning}

Pada data corpus, dilakukan pembersihan kalimat dari tautan atau URL, mention, hastags atau \#, menghapus kelebihan spasi, dan nomor menggunakan library tm.

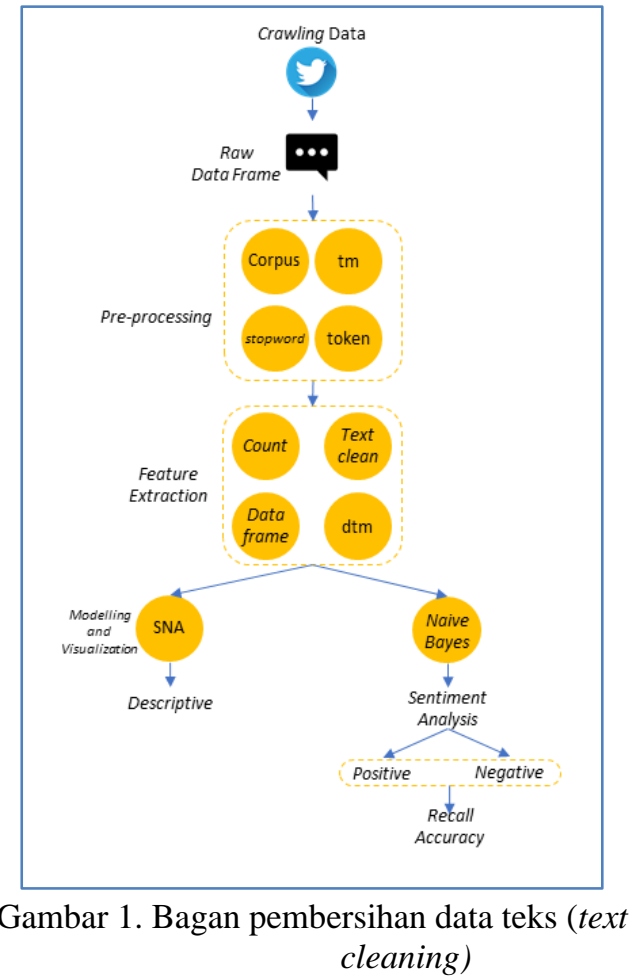

Stopwords Bahasa Indonesia

Pada struktur data yang sama, untuk menghapus kata hubung (konjungsi) atau kata-kata lain yang tidak bermakna, termasuk kata singkatan dilakukan tokenize kemudian mengeliminasinya dengan fungsi custome, yaitu stopwords-Indonesia.

Export Clean Text

Setelah ketiga tahapan di atas dilakukan, pada tahap akhir adalah mengubah kembali tweets dalam bentuk data frame dan menyimpannya dalam file excel dengan nama: databersih.

Analisis Jaring Sosial (Social Network Analysis) Social Network Analysis (SNA) merupakan salah satu analisis untuk melihat tingkat keeratan dan pengklasifikasian topik yang dibahas dalam jejaring sosial. Menurut Alamsyah, Andri dan Bratawisnu, Made K. (2018), analisis yang dapat dilakukan terkait jejaring sosial yang terbentuk adalah properti jaringan sosial. Properti sosial yang terbentuk berupa nodes, edges, dan degree untuk selanjutnya dianalisis Centrality-nya. 
Tabel 1. Pengertian properti jaringan

\begin{tabular}{|l|l|}
\hline $\begin{array}{l}\text { Properti } \\
\text { Jaringan }\end{array}$ & \multicolumn{1}{|c|}{ Definisi } \\
\hline Nodes & $\begin{array}{l}\text { Nodes adalah aktor individu dalam } \\
\text { jaringan yang dihubungkan oleh ties } \\
\text { (Oktora, Rio dan Alamsyah, Andry, } \\
\text { 2014) }\end{array}$ \\
\hline Edges & $\begin{array}{l}\text { Edges merepresentasikan interaksi } \\
\text { dua aktor (nodes) atau lebih (Anam, } \\
\text { Khairul M, dkk., 2021) }\end{array}$ \\
\hline Degree & $\begin{array}{l}\text { Degree merupakan ukuran keeratan } \\
\text { grup di dalam jaring (Network) }\end{array}$ \\
\hline Centrality & $\begin{array}{l}\text { Centrality adalah proses kalkulasi } \\
\text { terhadap relasi setiap individu dari } \\
\text { sebuah jejaring sosial (Susanto, } \\
\text { Budi. dkk., 2012) }\end{array}$ \\
\hline
\end{tabular}

\begin{tabular}{|l|c|c|c|c|c|}
\hline & Node 1 & Node 2 & Node 3 & Node 4 & Node 5 \\
\hline Node 1 & - & 1 & 1 & 0 & 0 \\
\hline Node 2 & 1 & - & 0 & 0 & 0 \\
\hline Node 3 & 0 & 0 & - & 1 & 1 \\
\hline Node 4 & 0 & 1 & 0 & - & 1 \\
\hline Node 5 & 0 & 1 & 1 & 1 & - \\
\hline
\end{tabular}

Gambar 2. Struktur matriks adjacency

\section{Betweenness Centrality}

Betweenness centrality pada dasarnya merupakan ukuran untuk melihat peranan sebuah node dalam jaring atau network. Menurut Pratama, Faustinus Y. (2018), betweenness centrality dapat digunakan untuk melihat node yang berperan sebagai bottleneck. Sebuah node dikatakan mempunyai peran penting jika menjadi communication bottleneck. Ukuran ini juga dapat digunakan untuk mengidentifikasi boundary spanners, yaitu aktor atau node yang berperan sebagai penghubung (bridge) antara komunitas. Ukuran ini dihitung dengan menjumlahkan semua garis atau path yang mengandung bottleneck node. Rumus di bawah ini digunakan dalam menghitung betweenness centrality:

$$
C_{i}^{B}=\frac{1}{(N-1)(N-2)} \sum_{j \in G, G \neq 1} \sum_{k \in G, k \neq i, k \neq j} \frac{n_{j k}(i)}{n_{j k}}
$$

berdasarkan skor eigen vector jaring antar node, dan ukuran peran sebuah node terhadap seluruh node. Untuk menentukan centrality, dalam penelitian ini menggunakan pendekatan betweenness centrality yang merupakan modifikasi dari degree centrality. Menurut Tabassum et al. (2018), degree centrality adalah jumlah interaksi atau edge yang terjadi pada suatu node tertentu dengan menggunakan formula berikut:

$$
C_{D}(i)=\sum_{j=1}^{n} a_{i j}
$$

di mana:

$C_{D} \quad$ : Degree centrality node ke- $i$

$a_{i j}$ : nilai baris ke- $i$ dan kolom ke- $j$ matriks adjacency

Degree centrality ditentukan oleh matriks adjacency. Menurut Santoso, Budi. dkk. (2012), nilai yang ada di setiap cell matriks adjacency menunjukkan informasi atas hubungan atau relasi antar aktor atau individu. Menurut Mamas, Christoporos (2018), struktur matriks adjacency untuk menentukan degree centrality Social Network Analysis (SNA) adalah sebagai berikut:

Joko Ade Nursiyono ${ }^{1}$, Chusnul Chotimah ${ }^{2}$ /

J Statistika Vol. 14 No. 1, (2021)

di mana:

$C_{i}^{B} \quad$ : bobot nilai betweenness centrality

$N \quad$ : jumlah node dalam suatu jaringan

$n_{j k} \quad$ : jumlah jalur (path) terpendek dari node ke-j ke node ke- $k$

$n_{j k}(i)$ : jumlah jalur (path) terpendek dari node ke-j ke node ke- $k$ yang melewati simpul ke- $i$

\section{Analisis Sentimen}

Analisis sentimen merupakan tool analisis untuk data yang bertipe teks dan kontekstual. Menurut Rozi, Imam F, dkk. (2012), analisis sentimen atau opinion mining merupakan proses memahami, mengekstrak dan mengolah data tekstual secara otomatis untuk mendapatkan informasi sentimen yang terkandung dalam suatu kalimat opini.

\section{Naive Bayes Classifier}

Naive Bayes Classifier (NBC) merupakan algoritma pengklasifikasian yang sering digunakan dalam permasalahan teks (Rozi, Imam F, dkk., 2012). Adapun atribut yang digunakan dalam NBC adalah data training, prior probability, serta posterior probability. Untuk menjelaskan teori Naive Bayes, proses pengklasifikasian memerlukan sejumlah 
petunjuk untuk menentukan kelas yang cocok bagi sampel yang dianalisis. Secara umum, peluang teorema Bayes yang disesuaikan dirumuskan berikut:

$$
P\left(C \mid F_{1}, F_{2}, F_{3}, \ldots, F_{n}\right)=\frac{P(C) \cdot P\left(F_{1}, F_{2}, F_{3}, \ldots, F_{n} \mid C\right)}{P\left(F_{1}, F_{2}, F_{3}, \ldots, F_{n}\right)}
$$

di mana $C$ merepresentasikan kelas dan $F_{1}, F_{2}, F_{3}, \ldots, F_{n}$ merupakan karakteristik yang diperlukan sebagai dasar pengklasifikasian. $P\left(C \mid F_{1}, F_{2}, F_{3}, \ldots, F_{n}\right)$ pada rumus tersebut merupakan posterior probability, yaitu peluang masuknya sampel karakteristik tertentu dalam kelas $C$. Sedangkan $P(C)$ merupakan prior probability, yaitu besarnya peluang munculnya kelas $C$ sebelum sampel tersebut masuk. $P\left(F_{1}, F_{2}, F_{3}, \ldots, F_{n} \mid C\right)$ merupakan peluang munculnya karakter-karakter sampel kelas $C$. Dan $P\left(F_{1}, F_{2}, F_{3}, \ldots, F_{n}\right)$ disebut sebagai peluang munculnya karakter sampel secara global atau disebut evidence. Setelah sentimen untuk masing-masing record terbentuk, kebaikan model Naive Bayes Classifier dalam penelitian ini diukur menggunakan Recall Accuracy. Menurut Rozi, Imam F, dkk. (2012), Recall merupakan rasio jumlah dokumen yang relevan yang ditemukan terhadap total jumlah dokumen relevan yang dikumpulkan. Nilai recall biasanya ditunjukkan dalam satuan persen (\%). Ukuran ini merupakan proxy performa model Naive Bayes Classifier dalam mengevaluasi kecocokan pengklasifikasian sentimen seluruh sampel. Berikut ini adalah rumus penghitungan recall accuracy (Handayani, Fitri dan Pribadi, Feddy S., 2015) :

$$
\text { Recall Accuracy }=\frac{T P}{T P+F P}
$$

di mana:

$T P$ : klasifikasi sentimen yang benar sesuai model Naive Bayes

FP: klasifikasi sentimen yang salah sesuai model Naive Bayes

Berdasarkan nilai recall accuracy, semakin besar nilai persentasenya, maka menunjukkan hasil pengklasifikasian model Naive Bayes Classifier semakin baik.

\section{HASIL DAN PEMBAHASAN}

Hasil pengolahan dengan menggunakan Social Network Analisis (SNA) terbentuk 5 klaster. Klaster 1 memiliki 73 anggota, klaster 2 memiliki 5 anggota, klaster 3 memiliki 1 anggota, dan klaster 4 memiliki 1 anggota, serta klaster 5 memiliki 14 anggota.

Joko Ade Nursiyono ${ }^{1}$, Chusnul Chotimah ${ }^{2}$ /

J Statistika Vol. 14 No. 1, (2021)
Hasil dari centrality summary didapatkan nilai minimum sebesar -0.028, kemudian quantil pertama sebesar 0.010, dan nilai maksimumnya sebesar 0.073. Berdasarkan summary tersebut, nilai maksimum centrality terdapat pada record ke-90 dan sekaligus merupakan bottleneck node, yaitu aktor utama penyebaran informasi antar klaster dengan kalimat tweet, "Pemerintah berencana mengenakan Pajak Pertambahan Nilai (PPN) terhadap sejumlah kebutuhan masyarakat banyak, termasuk di antaranya sembako dan jasa pendidikan (sekolah). Apa muara dari permasalahan ini? Simak analisis selengkapnya." Dari 5 klaster yang terbentuk, record ke-90 ini masuk dalam klaster sendiri, yaitu klaster 4 (terlihat node warna kuning pada gambar 3).

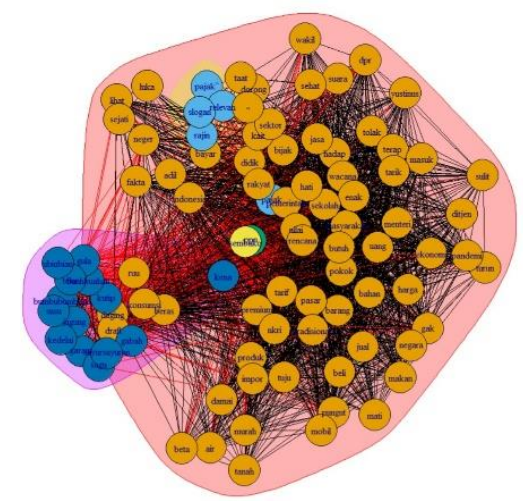

Gambar 3. Hasil olah social network analisis (SNA)

\section{Analisis Sentimen}

Twitter merupakan salah satu media sosial yang biasa digunakan untuk melihat opini masyarakat. Berdasarkan hasil olah data dari twitter, terdapat beberapa kata yang paling banyak muncul dalam tweet terkait isu PPN sembako dan jasa pendidikan. Kata yang sering digunakan yaitu "pajak", "ppn", "pemerintah", "kena", "rakyat", dan tentunya masih banyak kata-kata juga digunakan dalam tweet. Artinya, secara umum masyarakat menggunakan satu kata dari kelima kata tersebut dalam unggahan tweet-nya terkait kebijakan pengenaan PPN sembako dan jasa pendidikan (lihat gambar 4). 


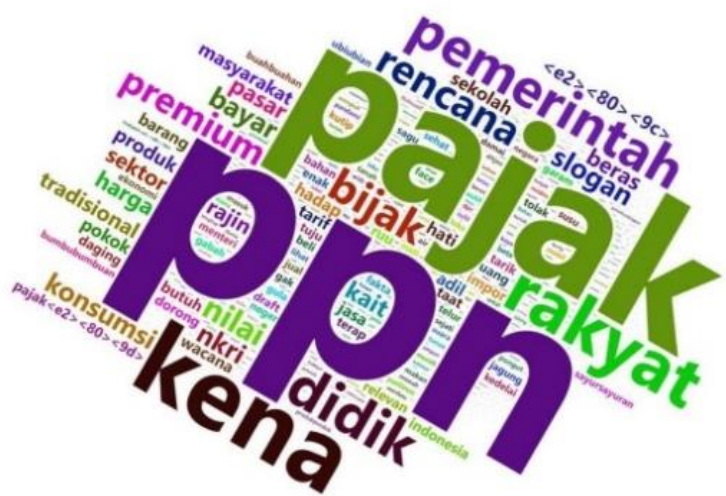

Gambar 4. Hasil olah kata Twitter

Pada gambar 5 terlihat bahwa pemberitaan mengenai PPN sembako dan jasa pendidikan jika dikelompokkan berdasarkan emosi menghasilkan 5 kelompok emosi. Dari kelima kelompok, emosi kata yang paling banyak adalah emosi anger (amarah), yakni sebanyak 3982. Artinya, mayoritas respon masyarakat terhadap kebijakan pengenaan PPN sembako dan jasa pendidikan diidentifikasikan oleh $R$ Studio sebagai wujud keamarahan.

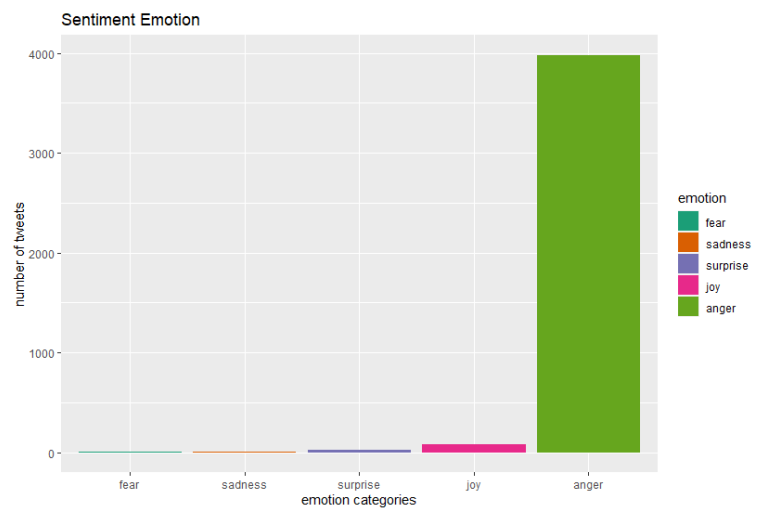

Gambar 5. Hasil olah klasifikasi kata berdasarkan emosi

Dengan menggunakan algoritma emosi kata, setiap kata dalam setiap tweet masyarakat akan terdeteksi dan terklasifikasikan dalam beberapa jenis emosi yang sekaligus menunjukkan ekspresi tweet yang diunggah ke media sosial Twitter, yaitu fear, sadness, surprise, joy, dan anger. Dari hasil polarisasi emosi setiap kata dengan R, terbentuk sebanyak 5 kelompok awan kata (wordcloud). Setiap kata yang paling banyak muncul pada masing-masing kelompok ditunjukkan oleh ukuran kata (font size) yang paling besar. Sedangkan kata yang paling kecil dalam setiap kelompok merupakan kata dengan frekuensi kemunculan paling kecil dalam tweet masyarakat.

Joko Ade Nursiyono ${ }^{1}$, Chusnul Chotimah ${ }^{2}$ /

J Statistika Vol. 14 No. 1, (2021)

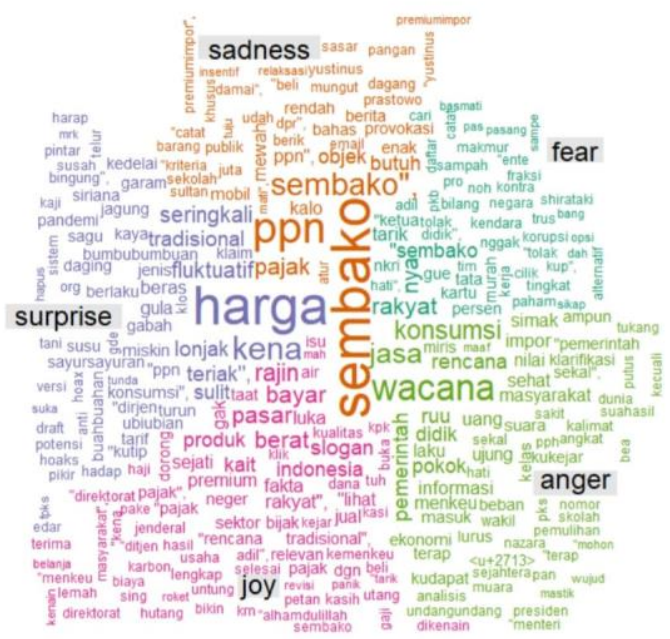

Gambar 6. Hasil olah klasifikasi kata berdasarkan emosi

Untuk mempertajam emosi setiap kata, dilakukan proses polarisasi emosi dengan hasil pada gambar 6. Terlihat, sejumlah kata yang masuk pada emosi anger (keamarahan) dan muncul dalam tweet masyarakat yaitu "wacana", "pemerintah", "beban", dan "masyarakat". Lalu kata yang masuk dalam emosi surprise (mengejutkan) di antaranya "harga", "fluktuatif", "lonjak", dan "miskin". Serta kata yang masuk kategori joy (kegembiraan) diantaranya kata "rajin", "bayar", "pajak", dan "bijak".

Sedangkan kata yang terkandung dalam tweet masyarakat sebagai emosi fear (ketakutan) di antaranya "tolak", "korupsi", "sembako", "rakyat". Dan kata yang dikategorikan emosi sadness (kesedihan) di antaranya "pajak", "sembako", "sasar", dan "dagang".

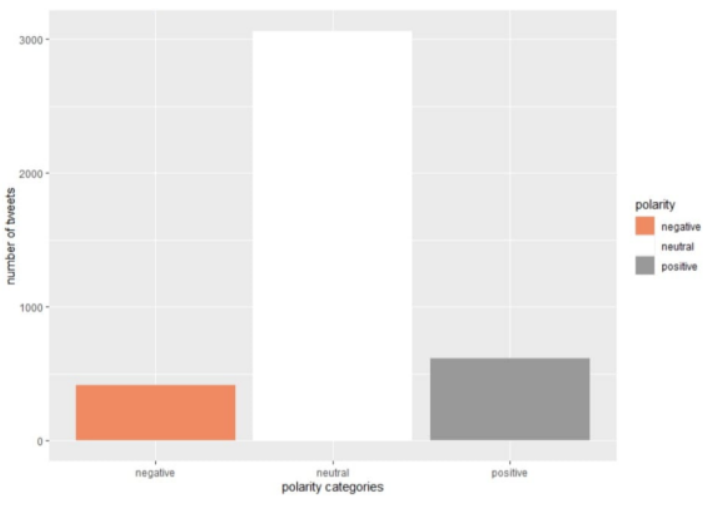

Gambar 7. Hasil olah sentiment analysis

Setelah sentimen untuk masing-masing kalimat terbentuk, kebaikan model Naive Bayes 
Classifier dalam penelitian ini diukur menggunakan Recall Accuracy. Hasil penghitungan Recall

Accuracy menunjukkan bahwa untuk Accuracy Classified sebesar 74.865 persen sementara persentase untuk Incorrectly Classified Instance sebesar 25.135 persen. Pada gambar 7, terlihat bahwa dari 4090 data twitter terkait topik ppn sembako dan jasa pendidikan, ada sebanyak 3062 data yang berhasil diklasifikasikan sentimennya dengan benar dan sebanyak 1028 data twitter lainnya tidak berhasil diklasifikasikan dengan benar.

Pada tabel 2 dapat dilihat bahwa dari 413 tweet yang diklasifikasikan bersentimen negatif ternyata semuanya masuk sentimen netral, dari 615 tweet bersentimen positif, ternyata semuanya masuk klasifikasi sentimen netral, hanya sebanyak 3062 tweet saja yang diklasifikasikan menurut sentimen yang benar (yaitu netral).

Tabel 2. Klasifikasi prediksi sentimen model naive

\begin{tabular}{lccc}
\multicolumn{4}{c}{ bayes } \\
Prediksi & Negatif & Netral & Positif \\
\hline Negatif & 0 & 0 & 0 \\
Netral & 413 & 3062 & 615 \\
Positif & 0 & 0 & 0 \\
\hline
\end{tabular}

Sumber: hasil olah $R$ Studio versi 4.0.3

\section{KESIMPULAN DAN SARAN}

1. Pengolahan data tweet ppn sembako menggunakan Social Network Analisis (SNA) menghasilkan 5 klaster dengan record ke-90 merupakan bottleneck node yaitu aktor utama penyebaran informasi antar klaster.

2. Hasil analisis sentimen secara umum masyarakat menggunakan satu kata dari kelima kata yang sering digunakan dalam tweet terkait pemberitaan ppn sembako dan jasa pendidikan yaitu pemeritah, pajak, ppn, didik, rakyat dan tentunya masih banyak kata-kata juga digunakan dalam tweet.

3. Hasil penghitungan Recall Accuracy menunjukkan bahwa untuk Accuracy Classified sebesar 74.865 persen sementara persentase untuk Incorrectly Classified Instance sebesar 25.135 persen.

4. Hasil klasifikasi berdasarkan emosi terbentuk 5 ekspresi fear, sadness, surprise, joy, dan anger dan emosi kata yang paling banyak adalah emosi anger (amarah), artinya, mayoritas respon masyarakat terhadap kebijakan pengenaan PPN sembako dan jasa pendidikan diidentifikasikan oleh R Studio sebagai wujud keamarahan.

Joko Ade Nursiyono ${ }^{1}$, Chusnul Chotimah ${ }^{2}$ /

J Statistika Vol. 14 No. 1, (2021)
5. Kendati masih wacana, ternyata di media sosial Twitter sudah terbentuk sentimen. Dengan demikian, sebaiknya pengumuman kebijakan PPN sembako dan jasa pendidikan diumumkan secara detil agar tidak menimbulkan salah persepsi di masyarakat.

\section{DAFTAR PUSTAKA}

Anam, Khairul M., dkk. 2021. Analisis Kesiapan Masyarakat Pada Penerapan Smart City di Sosial Media Menggunakan SNA, Jurnal Rekayasa Sistem dan Teknologi Informasi, 5(1), 69-81.

Alamsyah, Andry. dan Bratawisnu, Made. K. 2018. Social Network Analysis Untuk Analisa Interaksi User Media Sosial Mengenai Bisnis EComerce (Studi Kasus: Lazada, Tokopedia, dan Elevenia . Jurnal Manajeman dan Bisnis, 2(2), 107-115.

DJP Buka 3 Alasan Pemerintah Pungut PPN Sembako dan Sekolah. 2021. https://www.cnnindonesia.com/ekonomi/20210 614101335-532-653968/djp-buka-3-alasanpemerintah-pungut-ppn-sembako-dan-sekolah, diakses tanggal 21 Juni 2021.

Handayani, Fitri dan Pribadi, Feddy, S. 2015. Implementasi Algpritma Naïve Bayes Classifier dalam Pengklasifikasian Teks Otomatis Pengaduan dan Pelaporan Masyarakat melalui Layanan Call Center 110, Jurnal Teknik Elektro, 7(1), 19-24.

Mamas, Christoforos, 2018. The SAGE Encyclopedia of Educational Research, Measurement, and Evaluation, Chapter Title: "Matrices (in Social Network Analysis)", SAGE Publication, Inc, Thousand Oaks.

Nurzahputra, Aldi dan Muslim, Much A. 2016. Analisis Sentimen pada Opini Mahasiswa Menggunakan Natural Language Processing, Seminar Nasional Ilmu Komputer (SNIK 2016)Semarang, 10 Oktober 2016, 114-118.

Oktora, Rio dan Alamsyah, Andy. 2014. Pola Interaksi dan Aktor yang Paling Berperan pada Event JGTC 2013 melalui Media Social Twitter (Studi menggunakan Metode Sosial Networking Analysis), Jurnal Manajemen Indonesia, 14(3), 201-209. 
J Statistika Vol. 14, No. 1, (2021), Hal. 52-58

Pratama, Faustinus Y. 2018. Simulasi Jejaring Jalan Kota Pontianak Dengan Betweeness Centrality dan Degree Centrality, Jurnal TIN Universitas Tanjungpura, 2(1), 1-6.

Rozi, Imam F, dkk. 2012. Implementasi Opinion Mining (Analisis Sentimen) untuk Ekstraksi Data Opini Publik pada Perguruan Tinggi, Jurnal EECCIS, 6(1), 37-43.

Setatama, Mahdi, S. dan Tricahyono, Dodie, 2017. Implementasi Social Network Analysis dalam Penyebaran Country Branding "Wonderful Indonesia", 2(1), 91-104.

Susanto, Budi, dkk. 2012. Penerapan Network Analysis dan Penentuan Centrality Studi Kasus Social Network Twitter, Jurnal Informatika, 8(1), 1-13.

Tabassum, Shazia, dkk. 2018. Social Network Analysis: an Overiew, Original Article Jurnal Sectoin. 